\title{
ECUMENICAL INITIATIVES IN SOUTHERN RHODESIA: A HISTORY OF THE SOUTHERN RHODESIA MISSIONARY CONFERENCE 1903-1945
}

\author{
Munetsi Ruzivo \\ University of Zimbabwe \\ Department of Religious Studies \\ ruzivo9_99@yahoo.com
}

\section{ABSTRACT}

The article seeks, first and foremost, to investigate the origins, growth and development of the Southern Rhodesia Missionary Conference (SRMC) from 1903 to 1945 . In the second place, the article will explore the formative factors that lay behind the rise of the ecumenical movement in the then Southern Rhodesia in 1903. In the third place, the study endeavours to examine the impact of the SRMC on the social, religious and political landscape of the country from 1903 to 1945. The research will make use of minutes of the SRMC, newspapers and books with information that date back to the period under investigation.

Keywords: Southern Rhodesia Missionary Conference (SRMC); Land Tenure Act; African education; African marriages; Maize Control Act; racial tensions

\section{HISTORICAL BACKGROUND OF THE SOUTHERN RHODESIA MISSIONARY CONFERENCE}

Christianity was introduced in the Mwenemutapa state around 1561 by the sole Portuguese Jesuit missionary, Goncalo da Silveira. The Jesuit missionary efforts of evangelisation must be situated in the context of the expansion of the Portuguese empire in the $16^{\text {th }}$ century AD. His mission abruptly came to an end within two and a half months after his arrival at the Mutapa court. After his death, the Jesuits were

\section{UNISA}


replaced by the Dominican missionaries who evangelised the Mutapa state from 1572 to 1751 (Mudenge 1986: 4-29). The second phase of the evangelisation of Southern Rhodesia was carried out by the London Missionary Society, a conglomeration of mainly Protestant denominations, and the Jesuits who came to Rhodesia in 1879. After encountering a number of setbacks, some members of two missionary societies teamed up with the British South African Company (BSAC) agents and encouraged Lobengula to sign the Rudd Concession in 1888, which effectively sealed the fate of the Matebele king. The BSAC assembled a Pioneer Column force that included two chaplains, one from the Roman Catholic Church and the other from the Anglican Church (Weller and Linden 1984: 23-24). The force occupied Mashonaland in 1890. By 1898 both the Shona and the Ndebele tribes had been conquered by the BSAC force. Churches carved zones or areas for themselves in order to establish mission stations for purposes of proselytising. The Shona and the Ndebele people became subjects of the BSAC by virtue of conquest. New laws and forms of government alien to Africans were introduced. In this context, missionaries sought to ameliorate effects of the oppressive rule by offering themselves as spokespersons in issues of labour, education, race relations and land tenure. It is against this background that the SRMC was formed.

\section{FORMATION OF THE SRMC}

The first ecumenical body formed in Southern Rhodesia was the SRMC. It was formed in Bulawayo in 1903 by Reverend Charles Daniel Helm, who was a member of the London Missionary Society (Baxter and Burke 1970: 451). The first aim of the SRMC was to promote Christian missions in Southern Rhodesia. Protestant missions needed a united front to promote Christianity. The second aim was to encourage fraternal spirit in the mission field, and the third aim was to delimit denominational boundaries of all Protestant mission churches. Collection of statistics and paper concerning missionary work constituted the fourth aim. New societies working in the colony were referred by government to the SRMC for information regarding vacant areas where they could possibly try to open mission stations (Beaver 1962: 255). The fifth aim was to secure uniformity in dealing with native customs and affairs. Generally, the Missionary Conference cooperated with and lobbied government on African social policy issues (Mills and Grafton 2003: 248).

The Roman Catholic Church at first did not join this conference, as they stuck to their motto of combating and extirpating the Protestant heresy wherever it appeared (Daneel 1971: 188). Jesuits were the vanguard of Catholicism since the days of the Counter-reformation. They were not interested in getting restricted by Protestants. The Rhodesian Herald of 24 December 1903 described the missionaries associated with the formation of the SRMC as 'sensible missionaries'. The paper informs us that the most sensible resolutions, with regards to the questions of native labour 
and education, were passed in 1903 by nine missionary churches represented in the SRMC. The SRMC held their first meeting in Bulawayo in 1903. Deliberations of the conference discussions focused on the need for native churches to cultivate selfsupport and government. The second most important item was the work of the Bible Society in South Central Africa. The third item dealt with social questions in relation to native life. The fourth item was the industrial training of natives. The fifth was the native liquor issue, and the sixth item was government grants to native education and their proportion to taxation. It should, however, be noted that in this year the Urban Councils Ordinance was promulgated. Racial segregation was officialised in the urban areas by this ordinance. Prior to the ordinance, Harare was a multiracial city and Africans dwelt in all its sections. Resolutions of the SRMC were communicated to the Rhodesian Administrator, Sir WH Milton (Rhodesian Herald 24 December 1903: 6).

\section{SRMC ON LAND TENURE AND AFRICAN EDUCATION}

A joint conference of the Northern and Southern Rhodesia Missionary Conference took place at Old Livingstone in 1908 (The Christian Express November 1908: 184). Delegates to the joint conference recommended that native commissioners instruct African chiefs to compel their subjects to send their children to school (The Christian Express November 1908: 183). The conference urged the two Rhodesian governments to increase the grant in aid to grade 1 schools to $£ 1$ per head, and 15.s per head in schools where instructors were whites. Grade 3 schools were recommended to receive $5 \mathrm{~s}$ per head per year. The two Governments were encouraged to abolish hut tax for the local school teachers, since the missionaries were responsible for the salaries of teachers. A thorny issue at the conference was the administration of law in relation to the natives. It was observed by the missionaries that whites were getting away with impunity even after causing bodily harm or death to natives (The Christian Express November 1908: 184).

The two joint missionary conferences recommended that the Southern Rhodesian Government increase the amount of land for natives, as land that had been set aside for them was inadequate. One more issue the conference discussed was the issue of coming up with a uniform ethnography for various Shona dialects (The Christian Express November 1908: 184). A proposal that African reserves be enlarged was accepted by government. Pursuing the agenda of African education, the next missionary conference took place in Salisbury in 1910. Missionaries who attended the conference deliberated on who was better qualified to organise the life of the Africans. Was it the government or the missionaries? Catholic missionaries taught the natives Christian religion and manual labour (Zvobgo 1980: 48). Father Andrew Hartmann agreed with the colonial administration that it was too early to teach natives how to read and write. Missionaries resented government control of 
African education. They wanted to run African education as they saw fit, rather than to be controlled by government. In the same year government appointed the Graham Commission to look into African education, sexual conduct, native marriage and labour in order to influence missionary policy of educating Africans (Zvobgo 1980: 48).

The BSAC was not interested in African education but in industrials that prepared Africans to work as labourers in industries, farms and mines. Missionaries and colonial authorities differed on this point because the provision of education by missionaries was meant to lure Africans to Christianity. In other words, schools provided the proselytising grounds of converting Africans to Christianity. The Graham Commission encouraged government to cooperate with missionaries in order to influence missionary policy so that the colonial authorities would retain control over the curriculum that was taught in school (Zvobgo 2009: 55-56). Findings of the commission recommended that African education follow a three-pronged approach, namely literacy, industrial and religious training. It was recommended that all schools be controlled by government (Mungazi 1999: 71).

The SRMC of 1913 concerned itself chiefly with issue of land tenure, which threatened to cut back land reserved for the Africans under the Matabele Order in Council of 1894 (Rifkind 1972: 53). Delegates to the conference were more interested to know to what extent the recommendations of the Southern Rhodesia Native Affairs Committee of Inquiry met with the approval of the missionaries, and to what extent the land tenure system hindered missionary work, and lastly what missionaries would suggest for change in the future (The Rhodesian Herald 25 July 1913: 14). Some of the recommendations of the Native Affairs Committee were met with general approval, including the one that advocated for the principle of the Glen Grey Act of South Africa of 1894.

The land tenure system in Southern Rhodesia was divided into four namely: (1) communal in native reserves; (2) communal on the BSAC (Commercial Branch) land for which adult males paid 1 pound per year; (3) resident at private farms, at varying rentals; and (4) the residence on private farms under labour agreements. The SRMC approved without reservation communal native reserves. The second category of land tenure was deemed by the SRMC as a hindrance to mission work because the BSAC would not grant leases to missionaries on the same land. Residence on private farms for rent was criticised but residence on farms under a labour agreement was approved by all the churches represented in the council (The Rhodesian Herald 25 July 1913: 14).

Delegates to the conference were divided on the idea that natives should not be allowed to acquire land by franchise or lease, outside of the native reserves. The SRMC argued that if ever there was to be such a provision, it should operate in the case of white people in relation to land in the reserves. The majority of the missionaries were of the view that natives paying rent to the Company Commercial 
Branch should not be removed from the BSAC (Commercial Branch) lands. The reason was that their services were thought to be of value in the future. They were required to keep the roads repaired in the reserves. The SRMC were again divided on the Graham Commission's findings that native reserves were adequate for the present and future needs of Africans. Some delegates argued that the soils in the native reserves were poor for agricultural commercial activities. In spite of their concerns over the shortage of land in areas reserved for Africans, the SRMC accepted the findings of the Graham Commission and recommended that its findings be implemented (The Rhodesian Herald 25 July 1913: 14).

\section{SRMC AND AFRICAN MARRIAGES}

The SRMC of 1915 dealt with the issue of native marriages. Missionaries were of the view that native customary marriages must be discouraged as they did not condone other unions. Missionaries in the SRMC advocated for marriage by civil law, which excluded all other unions (West 2002: 81). This move by the missionaries was a response to the Marriage Ordinance Act of 1901 which seems to have recognised the African practice of paying lobola (Bride price) by stipulating a fixed amount of four head of cattle or 20 pounds. The move had not gone down well with the missionaries, who sought to influence government policy on African marriages.

In 1916 the Native Adultery Punishment Ordinance was enacted by colonial authorities and adultery was criminalised. In the following year, 1917, the Native Marriage Ordinance was enacted. It was designed to formulate a legal structure for both understanding and enforcing marriage practices among the Shona people. Shona perception of marriage, kinship and social relationships would be radically shifted as a result of this ordinance. In 1918 the SRMC convened at Great Zimbabwe and in its deliberations it dwelt on pretty much the same issues as at the previous conferences. On marriages, missionaries recommended the prosecution of African men who, having married in the church, proceeded to marry a second wife. The Southern Rhodesia Premier was agreeable to this proposal (SRMC 1930: 18).

In the SRMC of 1922 the issues of marriage and lobola were discussed On lobola and marriage the SRMC recommended the removal of the objectionable custom of lobola altogether. Father Alfred Burbridge, a Jesuit Catholic priest, moved the motion for the adoption of a resolution on the issue and was supported by Archdeacon E.H. Etheredge, an Anglican priest. Father Burbridge said that a limit to what Africans had to charge had to be imposed in order to foil avarice by old African men. A resolution that required the overhaul of the Marriage Act of 1917, which Father Burbridge said was a bad imitation of the Natal law, was adopted.

Irregular methods of Christian evangelisation by the Apostolic Faith Mission were raised by Father Burbridge. The context of the issue was that the Apostolic Faith Mission of South Africa had applied for membership with the SRMC, but it 
happened that reports had reached the conference that the church in question was practising irregular methods of baptism. In his own words, he said:

Many of these boys were malcontents who had left other mission churches...their instructional periods were not long enough to enable them properly to take up the work of teaching Christianity. They sometimes carry on the teaching in a curious way. For natives to become Christians at 24 hours' notice, subscribing to some form of peculiar diet and then being taken down to a river to be baptised in batches at six-pence a time - was that in accordance with the decency and dignity of Christian propaganda. It was disgusting and scandalous and they could not give their approbation to it in any way. (The Bulawayo Chronicle 27 May 1922: 8)

The other issue brought up at the conference was the voice of native opinion on constitutional issues. Reverend John White proposed the following resolution on native constitutional issues:

In the opinion of the Missionary Conference it is vital to the best interest of the native people of Southern Rhodesia, as also to its good government, that when a change of government shall take place, the new constitution shall embody Imperial guarantees on the lines of the recommendations of Lord Buxton. Further, it is our opinion that it will greatly assist maintaining tranquillity in the country if some provisions be made to the new constitution whereby the native people may express their mind on affairs that concern their welfare. We suggest that something in the form of a native advisory council be set up, and that these be eventually empowered to select Europeans that represent them in the Legislative Assembly. (The Bulawayo Chronicle 27 May 1922: 8)

\section{ARTHUR SHEARLY CRIPPS AND JOHN WHITE}

At the same conference the land tenure was discussed. The delegates to the conference recommended that 50 per cent of unassigned land adjacent to reserves be availed to the natives for purchase. John White and Arthur Cripps, who were outspoken missionaries in the SRMC, strongly urged the SRMC to defend the natives on this issue. On a different issue altogether, missionaries and colonial authorities closed ranks over the issue of the looming referendum that was to decide the fate of the settlers. The SRMC encouraged the settlers to vote for a responsible government and reject absorption into the Union of South Africa (The Bulawayo Chronicle 27 May 1922: 8)

African industrial training continued to engage the minds of the missionaries and government officials with heaps of praise for Keigwin's enterprise. Such an undertaking by the Director of Native Development would deal a decisive blow to African beliefs about witchcraft, which were perceived by the colonial authorities as having a retrogressive effect on native development. In this regard, Moffat observed:

A judicious combination of scholastic and industrial education has been found to be the best method of raising the native in the scale of civilisation and of making him a more useful 
member of the state. The influence of the missionary is slowly but surely freeing the native from deadly influence of the spirit world, raising the level of his intelligence and raising his capacity as a wage earner. (The Bulawayo Chronicle 27 May 27 1922: 8)

Although there were government officials who believed that Keigwin's approach would solve the native problem in the area of education, the Premier was not under such an illusion that believed witchcraft could be extirpated by the building of industrial schools for Africans. He pointed out that for the first time it seemed as if government was competing with missionaries in the provision of education for the Africans, with a huge amount of money having been set aside for the task (The Bulawayo Chronicle 27 May 1922: 8). Franklin Parker pointed out that this new venture marked government entry into African education (Parker 1960: 127). Up until 1920, native education had remained in the hands of missionaries. This monopoly only ended when Keigwin introduced two industrial schools, Domboshava and Tjolotjo. Missionaries had not been in favour of competing with government in providing African education. If government provided African education that would mean missionaries could no longer use African schools as proselytising grounds.

\section{SRMC AND GOVERNMENT SEGREGATION POLICIES}

The year 1923 is significant in that the BSAC rule gave way to Southern Rhodesia becoming self-governing. Rhodesian settlers refused to be amalgamated into the Union of South Africa, thereby choosing to be self-governing. Some measure of influence and control in the responsible government was retained by the British Crown, just as they had done with the BSAC earlier (Randolph 1985: 1). The SRMC took issue with the government on the transfer of African education from the Department of Native Education to the Department of Native Administration. Hallencreutz points out that the missionaries were critical of the separation of African education from European education. The move to responsible government intensified racial segregation in Southern Rhodesia (Hallencreutz 1998: 93).

Up until 1940 there were no secondary schools in Southern Rhodesia. There was a move to strictly control African life. The movement of African Independent Church preachers was highly restricted by Southern Rhodesian authorities. To achieve the objective, the Rhodesian Government came up with the idea of a Native Preachers' Bill in 1924. This dominated the SRMC of 1924 which was held in Salisbury. Cripps and White successfully influenced the SRMC in rejecting the Bill designed to control the activities of preachers of the African Independent Churches (Steele 1975: 158). Although they criticised the Bill they allowed government to restrict activities of the African Independent Church preachers. Attendees of the conference were unsettled over the issue of the Watchtower in Southern Rhodesia. The Watchtower was a millennial movement founded by Charles Taze Russell in 1879 in the United States 
of America. In Africa it did not have European supervision. In Southern Rhodesia the movement was propagated by labour migrants from Nyasaland. Members of the missionary conference were of the view that eventually white missionaries would find themselves jobless if independent preachers were encouraged to work with no supervision (The International June 13 1924: 4). In 1924 members of the PhelpsStocks Commission addressed the SRMC. Government provided huge sums of money for native education. Missionaries on their part had to concede to government inspection (Weller and Linden 1984: 75-76).

The issue of land tenure dominated the SRMC of 1926. Cripps and White encouraged members of the conference to keep pressing government for 50 per cent more, but they did not succeed. The Morris Carter Commission, which had been tasked with soliciting people's views, recommended that 37 per cent of the available hectares be set aside for the Africans. Some of the missionaries accepted what government had offered. Weller and Linden observe:

The majority of members felt that "half a loaf is better than no bread", and protest against the "the White Man's Magna Carter" was muffled. Not only were the best areas of farmland reserved for Europeans, but Africans were excluded from buying land in the urban areas... Cripps left for England, and although he returned later, he never again played a significant part in the conference. (Weller and Linden 1984: 26-27)

Refusal of Africans to move from areas that had been designated as European, prompted the Rhodesian authorities to come up, in 1926, with legislation known as the Native Affairs Act, which criminalised African contemptuous behaviour against the Chief Native Commissioner or officers administering native affairs. White, who was president of the SRMC, castigated the piece of legislation as autocratic and resembling the Natal one. Using his influential position, he attacked every piece of Rhodesian legislation which he saw as discriminating against Africans (Steele 1975: 160).

Godfrey Huggins became prime minister in 1933. He initiated parallel development in the country. There was an increased separation of Europeans and Africans. This was felt in the SRMC. In 1928 White was instrumental in the founding of the Southern Rhodesia African Missionary Conference (SRAMC). The idea had been mooted as early as 1921 when Thompson Samkange, a Methodist evangelist, made a call for the setting up of a Wesleyan Evangelists and Teachers Convention. He became the secretary to its Mashonaland chapter. In the following year he was elected secretary of the Wesleyan National Convention in which he made a call for the setting up of an interdenominational African Christian organisation:

We have long been separated...now we see for ourselves that Union is the only weapon to fight with darkness. Even the Government will not recognise things done individually. We must unite and speak with one voice...we black people making a great cry which shall be heard in every place in South Africa so that it will get into the hearts of those forming the Government...we have seen that the European Missionaries are united together, well. Then 
what stops us black people from being like the whites? Are we not also men borne with the same spirit of manhood within us? Let us stand together. (Ranger 1995: 14)

In the next two years Samkange made use of the next Wesleyan convention to campaign for the need of an African Missionary Conference modelled along the lines of the white dominated SRMC. Assured of White's support, a Wesleyan Convention in Gatooma set up a steering committee of the Southern Rhodesia African Missionary Conference (SRAMC). He guided the committee as its secretary. The first meeting was held in Salisbury in 1928 under the chairmanship of White who chaired the two missionary conferences. He was at the helm of the movement for the next 20 years (Ranger 1995: 14). White attacked other pieces of legislation such as the Juveniles Affairs Act and the proposed Land Apportionment Act. He was opposed by the white farmers to such an extent that his support in the SRMC steadily waned, and at the 1930 SRMC conference he was not retained in the executive (Steele 1975: 51).

Samkange did not only encourage his colleagues to join Christian organisations. He encouraged them to join secular organisations of the time, such as the Rhodesian Native Association; Bantu Voters' League of Martha Ngano; and the Bantu Community of Bulawayo, of which he was a member. In Christian circles he served in the SRMC Committee on Lobola and he was also secretary to the Young Man Christian Union. Dickson Mungazi has observed that the reports of these inquiries were used to design policies that entrenched the power base of the settler regime (Mungazi 1989: 265). White's organisational solution was concession to the general pervasiveness of Southern Rhodesian segregation (Steed and Sundkler 2000: 806). The formation of the Southern Rhodesian African National Missionary Conference (SRANMC) stands out as one of the greatest achievements of the SRMC in 1928.

The SRMC of 1930 mainly focussed on the Native Marriage Act, the Land Apportionment Act, Native Councils Bill and revenue from native purchase areas. These issues were continuing from previous conferences and were not necessarily new themes. On Native Marriage Ordinance, missionaries pushed for the prosecution of people who took second wives after having married in church. The Premier, Cecil Rodwell, advised the missionary conference that it was unnecessary to threaten the natives. It appears that missionaries wanted to turn the country into a confessional state. They were not satisfied with cooperation with government in areas of national development (SRMC 1930: 18).

The SRMC expressed regrets that government had not agreed to its request that half of the unassigned land (a total of 17793300 hectares) be made available for native purchase. They wanted to see justice on the issue. Some members of the conference asked the Premier if clause 23 of the Land Apportionment Act meant that missionaries could not charge rent to tenants on mission land. The Premier promised to rectify the anomaly. Still on the same issue, missionaries complained that land for village communities had not been set aside according to recommendations they had made to the Morris Carter Commission. Once again the Premier replied that some 
of the land had not been found suitable for the reserves (SRMC 1930: 18). During the course of the conference it was observed that no land had been set aside for the development of townships in the rural areas.

\section{SRMC AND AFRICAN SOCIAL LIFE}

Beer control was another issue that was discussed in the conference of 1930. Missionaries sought to limit the drinking behaviour of Africans. In connection with the liquor issue, Rev. Frank Noble of the Wesleyan Methodist Missionary Society proposed the following resolution:

That steps be taken by the Government to lay down that at the end of a definite period, of say one or two years, the brewing and sale of strong beer outside of the reserves and also in industrial areas situated on reserves, shall be "prohibited... That definite temperance instruction become part of the curriculum in all Kraal Schools...That no strong beer be allowed at Nimbes, that is communal ploughings, reapings, and thrashing of grain, and that the responsibility for such an order be not upon the Kraal head, but upon the Native Department. If that could be done one of the darkest blots upon the life of the Reserves would be removed" ...that far more effective steps be taken to put into effect the present Ordinance, which prevents the sale in Kraals of strong beer. That would be one way of mitigating excessive Sunday beer drinking. (SRMC 1930: 4-5)

The resolution would have far-reaching consequences on the social life of the natives at the time and in the future. It is from this resolution that the fate of strong African beer was sealed. Beer brewing by Africans in towns or rural areas would be criminalised. Anyone caught brewing forbidden liquor would be prosecuted.

In the area of social justice White pleaded with government to allow competent people to gather evidence rather than rely on evidence collected by native police officers. He was concerned with possible miscarriage of justice against the natives and therefore he pleaded with government to understand that the judicial system they had brought was altogether foreign to the natives. In his view there was a need to revisit the judicial system to make sure that natives were tried fairly. Members of the SRMC stated that more often natives were beaten and denied food, forcing them to admit to crimes they had not committed. The SRMC also complained that a lot was lost by way of interpretation. White implored government to allow native commissioners experienced in dealing with natives, to assist the judges (SRMC 1930: 21).

The other issue bordered on the employment of native girls. In the early period, the colonial government mainly employed men only. With the passage of time there arose the question of the suitability of some domestic jobs for men. Finally, they resolved that young female ladies could be employed on the condition that they stayed in the same house with their employers and the wives of the employers would take responsibility for their social welfare and moral development (SRMC 1930: 5). 


\section{GOVERNMENT CONTROL OVER AFRICAN EDUCATION}

A more absorbing issue was the question of native education. This issue had been discussed at nearly all previous conferences. The Director of Native Development, $\mathrm{Mr} \mathrm{H}$ Jowitt, issued an instruction that all schools were supposed to be registered, whether they were aided or not. He also clarified that those schools that were not registered and received a government grant, would eventually be closed. Government was asserting its control over African education. Regarding the unification of languages, a theme that had been discussed at several previous conferences, it was agreed that dialects in Mashonaland would be reduced to a standardised Shona (SRMC 1930: 6-7).

The missionary conference requested government that hospitals should be established. They recommended the training of native nurses and doctors to serve in the newly established hospitals and clinics. Government often cited lack of resources, but missionaries expressed their concerns over the relationship between revenue accrued from native taxes and the actual money used on services for natives. The point the missionaries were driving home was that revenue accrued from taxing Africans could be invested in African education. It was agreed that an inquiry would be made into the issue. Lastly the missionary conferences implored government to do away with forced labour, and move towards empowering the natives by opening to them avenues of academic and industrial education (SRMC 1930: 8).

At the SRMC of 1932, held at Victoria Falls, missionaries piled pressure on government to provide more education facilities for Africans as a way of stopping compulsory labour. The executive report on the proceedings of its meeting with the Premier stated that, on the question of compulsory labour, the Premier reported that the compulsory labour policy would continue but would gradually be eliminated. Compulsory labour could be eliminated if equal opportunities to education were provided by government. Still on the same issue of African education in the medical field, the director of medical services informed the executive that government position was that only British medical services could certify African trained nurses. However, there were missionaries who expressed concern over the health of native medical students. Government was requested to provide medical services to all training institutes and boarding schools (SRMC 1932: 3).

The control of African education by both government and mission churches served to create the ideal worker for government; and an ideal Christian for the missionaries. The result of the control was the continuous weakening of African cultural institutions and African kinship ties. Native education was a lynchpin of missionary enterprise and without it missionary work would have become difficult. Missionaries of course moderated the extremes of settler capitalism that threatened African identity, but they also manipulated the helplessness of the African for their own religious proselytising zeal. They lamented the reduction of grants in aid to 
unregistered schools, which they said signalled the closure of village schools. Missionaries pleaded with government to provide grants to girl children attending domestic training schools without any qualification. It is in this tassel of who had the power to control African education, the missionaries or the colonial government, that 'Jeans teaching' was introduced in Rhodesia (Summers 2002: 120).

The name 'Jeans teaching' is derived from the American Quaker Philanthropist, Anna T Jeanes, who sought to improve community and school conditions for African Americans after the American civil wars. They taught sanitation, cooking, basket making, chair making, and sewing (http://education.stateuniversity.com). The SRMC appreciated the role played by Jeanes and home demonstrators in schools and they recommended the teaching of hygiene in schools, both theoretically and practically. Connected to the theme of hygiene was the issue of leprosy. The conference noted that there were 7000 lepers in the colony. Jowitt informed the SRMC that government had set up treatment centres and he encouraged missionaries to train African nurses to help mitigate the problem.

The educational level of mission personnel was regarded by the Southern Rhodesian Government as a criterion by which denominations could be admitted into Southern Rhodesia. A closer analysis will show that the policy was directed at African churches and churches that were regarded as promoting separatism. The admission of the African Methodist Episcopal Church of Esau Nemapare would become a test case. The SRMC of 1932 stated as follows in a resolution:

That in the opinion of this Conference, the responsibility of decision concerning the granting or withholding of approval for the admission of new denominations into this territory, is definitely the concern of the Government, a responsibility which cannot be vested in the Missionary Conference. It is our conviction, however, that the utmost care should be exercised by Government in this connection, in order to prevent undesirable influences operating upon Native life. To this end it is respectfully recommended that the factors to be considered would include the nature of the representative views held, the previous record of the denomination, the educational and other credentials of the personnel, and the facilities at the disposal of the body concerned adequately to ensure the satisfactory direction and maintenance of the work proposed. (SRMC 1932: 12)

\section{SRMC AND THE EFFECTS OF THE MAIZE CONTROL ACT}

The Maize Control Act, which made it difficult for the natives to sell their maize to government, was discussed and the SRMC recommended the repealing of the Act or some form of relief for the natives. The SRMC was informed that correspondence with the concerned minister over the Maize Control Act did not achieve any result. The point here was that government was not prepared to give any relief to the hard-pressed African farmers. Missionaries resented the newly introduced quota 
system, whereby government would provide a quota of the total grants needed by the missionaries and then missionaries would meet the rest (SRMC 1934: 4-5). The SRMC encouraged the establishing of native savings banks and cooperative societies. Father Baker of the Community of the Resurrection introduced a discussion on the recently passed Land Tenure Act, which he said was working to the detriment of the natives by driving them from their ancestral lands; and then making it worse by controlling the price of maize produced by one segment of the population, namely the natives (SRMC 1934: 12). Related to the Land Tenure Act was the problem of native village settlements, which the conference recommended should be under government control. The cattle levy also came into focus, as captured below in the minutes of the SRMC:

That this Conference expresses its disapproval of the imposition of a levy of $3 \mathrm{~d}$ per head on Native-owned cattle, and objects to the conditions of Par. 3 sec. 3 of the Cattle Levy Act, 1934, requiring occupiers of private land to collect the levy of $3 \mathrm{~d}$ per head from Native owners of cattle. Such levy should be collected either by the Officials of the Native Affairs Department or by the Police. (SRMC 1934: 13)

\section{THE SRMC AND RACIAL TENSIONS}

Missionaries expressed dismay at the prospect of being required by law to collect this type of tax from the natives. What irritated the missionaries was that they were required to collect tax which they were not in sympathy with. The SRMC of 1936-1938 was more concerned with the place of Africans in the emerging capitalistic society. Missionaries did not give up on the issue of land; a subject that had been contentious since the inception of the SRMC. The settlers had appropriated the best land for themselves. In all instances missionaries had not made an outright condemnation of the self-aggrandisement of the settler regime, but sought to ameliorate the position of the African in the fast-changing society. At all the conferences (1936-1938) reports were formulated on the following issues: the land Apportionment Act; evangelised areas; relations of missions to emerging churches; religious education; native education and the issue of grants in aid; the training of native nurses; cooperation between Europeans and none Europeans; marketing of native produce; the issue of unpaid mission workers and native education; and the need for higher education and health services for rural people (SRMC 1936; 1938: 8-11).

Government removal of Africans from areas designated as European areas by the Land Tenure Act, prompted the Missionary Council to demand more land for Africans in the urban areas. Social issues dominated the SRANMC. It looked into the issues of native women co-habiting with Europeans. The admission of the Methodist Episcopal Church of Rev. Esau Nemapare became a test case for the admission of independent churches. Another sensitive social issue discussed in the same meeting, was perceived preference of halfcast children to natives. Most of the native pastors 
condemned the attitude as retrogressive. As regards African education, the native pastors were concerned with the amalgamation of kraal schools as well as town location schools and the impact this would have on African education. In brief, the SRANMC was more concerned with issues affecting Africans in their day-to-day living, such as the need for better wages; compulsory education for African children in urban areas; the need for higher education; the Maize Control Act; publication of laws in the Bantu Mirror; and promotion of African Catechists or African agents as superintendent of schools (SRMC 1936: 20-22; 1938: 19).

The full SRMC did not meet in 1940 as expected, but only its executive, and the scheduled SRMC conference was postponed to 1942. Race relation issues dominated the proceedings of the conference, as in past conferences. The same issues as in the past conferences were discussed. Partnership between missionaries and the State was evident by the attendance of government ministers and officials. In 1942-1944 conferences took place in the context of World War II. Objectives of the conference of 1942 were threefold: to encourage the fostering of unity of purpose in the promotion of Christian democracy; to handle Africans more humanely; and the encouragement of Africans to embrace Christian values. A significant event was the Catholic Church's withdrawal from the missionary conference for unspecified reasons in 1942. It is believed that the Anglican Church was not pleased with the constitution and therefore wanted certain clauses, dealing with the admission of new members to the SRMC, to be amended (SRMC 1942: 12). The admission of the Methodist Episcopal Church seems to have triggered concerns raised by Anglican delegates. Anglicans wanted the conference to vote whenever new members wanted to be admitted into the conference, rather than just to allow the executive to decide on the matter. Catholics and Anglicans at the time did not see the need for secondary school education for natives. Other mission bodies were willing to cooperate with government, which would provide funding for the building of secondary schools. A site was located in Goromonzi and at the conference the issue of appointing natives into the public services was debated, and a resolution to that effect was passed which stated:

This Conference is of opinion that the principle should be accepted and preparation be made now by suitable training for the fulfilment of the policy of encouraging the fullest possible development of African life in the Native areas, locations, and compounds, and the maximum possible contribution by Africans themselves in that development: that, public services being an integral part of true citizenship and therefore being available to Africans of well-developed capability, it should now be recognized that it is in the public interest to give opportunity to Africans to be appointed to Government and Municipal employment in the more responsible and highly paid posts. (SRMC 1942: 13)

The Conference took note of the National Christian Council of South Africa, which was formed in 1936. Perhaps this would herald the formation of a similar organisation in the near future. The 1944 SRMC conference took place in Victoria 
Falls. Government expressed its gratitude for the role played by the missionaries in the education sector during the war period. Up to 1944 missionaries still cherished the hope of making Africans a model of a Christian race (SRMC 1944: 10). African families would be taught Christian values. Today most churches are teaching programmes that are in line with this idea. What we see here was a cultural onslaught against everything and anything that was deemed unchristian. Areas of cooperation between missionaries and government in African education were explored by the delegates to the SRMC. It was observed that government and Africans were not too insistent on spiritual uplifting, but more on qualifications. Spiritual uplifting was the chief concern of the missionaries, as observed by Hadfield (SRMC 1944: 15).

\section{CONCLUSION}

In this study we have seen that the SRMC was formed in 1903 for purposes of promoting and encouraging Christian missions, delimitation of mission boundaries, and uniformity in dealing with native customs and culture. To achieve this objective, the SRMC formed a number of committees that tackled various issues which impinged on missions and relations between the natives and the settler regime. Africans had responded to the gospel message; and the missionaries sought to protect their hard won converts from the excesses of unmitigated settler oppression against the natives. They endeavoured to provide Western education to the natives, together with its industrial skills, in order to assist the natives in coping with the new dispensation of a capitalist colonial state. The SRMC became the intermediary between Africans and the colonial state.

\section{REFERENCES}

Baxter ,T.W and Burke, E.E. 1970. Guide to the historical manuscripts of Rhodesia. Salisbury: NAR, 451.

Beaver, R.P. 1962. Ecumenical beginnings in Protestant World Mission: A history of Comity. New York: Thomas Nelson, 225.

Daneel, M. 1971. Old and new in Southern Shona Independent Churches (volume. 1): Background and rise of the major movements. The Hague: Mouton, 188.

Franklin, P. 1960. African development and education in southern Africa. University of Texas Press: Kapa Delta Pi, 127.

Hallencreutz, C.F. 1998. Religion and politics in Harare 1890-1980. Studia Missionalia Upsaliensia No. LXXIII. Uppsala: Swedish Institute of Missionary Research, 93.

Mills, K. and Grafton, A. 2003. Conversion old and new. New York: Rochester University Press, 248.

Mudenge, S.I.G. 1986. Christian education at the Mutapa Court: A Portuguese strategy to influence events in the Empire of Munhumutapa. Harare: ZPH, 9-29. 
Mungazi, A.D. 1989. The struggle for change in southern Africa. New York: Taylor and Francis, 265.

Mungazi, A.D. 1999. The last British liberals in Africa: Michael Blundell and Garfield Todd. Westport: Praeger, 71.

Randolph, R.1985. Dawn in Zimbabwe. Gweru: Mambo Press, 1.

Ranger, O T. 1995. Are we not also men? The Samkange family and African politics in Zimbabwe 1920-64. Harare: Baobab, 14.

Rhodesian Herald, 24 December 1903: 6.

Rifkind, L.M.1972. Land apportionment in perspective. Rhodesian History: The Journal of the Central Africa Historical Association 3: 53.

SRMC. 1930. Proceedings of the Southern Rhodesia Missionary Conference, Bulawayo, 26-28 June 1930.

SRMC. 1932. Proceedings of the Southern Rhodesia Missionary Conference, Victoria Falls, Southern Rhodesia, 23-28 June 1932.

SRMC. 1934. Proceedings of the Southern Rhodesia Missionary Conference, Great Zimbabwe, June 1934.

SRMC. 1936. Proceedings of the Southern Rhodesia Missionary Conference, Salisbury, June 1936.

SRMC. 1938. Proceedings of the Southern Rhodesia Missionary Conference, Bulawayo, June 1938.

SRMC. 1942. Proceedings of the Southern Rhodesia Missionary Conference, Bulawayo, 1942.

SRMC. 1944. Proceedings of the Southern Rhodesia Missionary Conference, Bulawayo, 21-25 June 1944.

Steel, C. and Sundkler, B. 2000. The church in Africa. Cambridge: Cambridge University Press, 806.

Steele, M. 1975. With hope unconquered and unconquerable...: Arthur Shearly Cripps, 18691952. In Themes in the Christian history of Central Africa. Edited by O.T. Ranger and J. Weller. Los Angeles and Berkeley: University of California, 158.

Summers, 2002. http://education.stateuniversity.com/pages/2135/Jeanes-Teachers. html\#ixzz43APIsJMY (accessed 15/03/16).

The Bulawayo Chronicle, 27 May 1922: 8.

The Christian Express. 1 November 1908: A Journal of Missionary News and Christian Work ,Vol. XXXVIII(457): 183-184. Lovedale South Africa.

The International, 13 June 1924: 4.

The Rhodesian Herald, 25 July 1913: 14.

Weller, J. and Linden, J.1984. Mainstream Christianity to 1980: Malawi, Zambia and Zimbabwe. Gweru: Mambo Press, 26-27.

West, O.M. 2002. The rise of African middle class: Colonial Zimbabwe 1898-1965. Indianapolis: Indiana University Press, 81.

Zvobgo, J.M.C. 2009. A history of Zimbabwe 1890-2000 and postscript Zimbabwe, 2001-2002. New Castle: Cambridge Publishing Scholars, 48, 55-56. 
Zvobgo, J.R.1980. Government and missionary policies on African secondary education in southern Rhodesia with special reference to Anglican and Wesleyan Methodist Churches. $\mathrm{PhD}$ thesis, University of Edinburgh , 48, 55-56. 